\title{
The spread of Coxsackie B1 infection
}

\author{
T. W. HOSKINS, JOAN R. DAVIES, A. J. SMITH, KATHRYN COLLINGHAM, \\ AND ROMA N. CHAMBERLAIN \\ Christ's Hospital School, Horsham; Public Health Laboratory, Guildford; and Central Public Health \\ Laboratory, London
}

SUMmARY During June and July 19775 junior boys in a boarding school for 800 pupils became ill with a mild infection caused by Coxsackie B1. The school had been taking part in a vaccine trial, and paired blood samples had been taken from new entrants in October 1976 and October 1977. $18 \%$ of the boys susceptible to the infection developed antibodies. The results suggest that dormitories are more important than the day-to-day contacts in the spread of infection. The advisability of nursing children with known or suspected enterovirus infections in open wards in hospital is questioned.

The interfamilial and institutional spread of Coxsackie B2 and B5 viruses has been well documented (Carmichael et al., 1968; Broughton and Gostling, 1969; Lapinleimu and Kaski, 1972; Eilard et al., 1974), but there have been few accounts of Coxsackie B1 (Yodfat and Nishmi, 1973). Communicable Disease Reports (Public Health Laboratory Service, 1964-1977) show that since 1967 there have been two small outbreaks in England and Wales, the first began in 1970 and the second in 1976 (Figure). Each lasted two years, the distribution of cases being biphasic, peaking in the summer months.

Christ's Hospital is a boarding school for 800 pupils aged between 11 and 19 years. The younger boys live in six houses. They are in forms for teaching, and then are split into sets for mathematics, French, Latin, etc., which are constituted differently from forms, and all the boys use a central dining hall. The range of contacts during the day must, therefore, be large. During June and July 1977, 5 junior boys became ill with a mild infection caused by Coxsackie B1. The school had been taking part in a trial of inactivated influenza vaccine (Hoskins et al., 1976), and paired blood samples had been taken in October 1976 and October 1977 from 124

\footnotetext{
Christ's Hospital, Horsham, Sussex

T. W. HOSKINS, medical officer

Public Health Laboratory, Guildford, Surrey

JOAN R. DAVIES, deputy director Public Health Laboratory Service, and consultant microbiologist

A. J. SMITH, principal microbiologist

Public Health Laboratory, Reading, Berks.

RATHRYN COLLINGHAM, registrar and trainee microbiologist

Central Public Health Laboratory, London

ROMA N. CHAMBERLAIN, senior epidemiologist
}

new entrants. This paper describes the spread of the infection.

\section{Methods}

Virus isolation. Throat swabs were collected into transport medium at the onset of illness. In the laboratory the specimens were inoculated into primary rhesus monkey kidney, human embryonic lung fibroblast, and Hela cell tissue cultures. These were incubated, rolled at $35^{\circ} \mathrm{C}$ for 15 days, and examined daily for cytopathic effect. Coxsackie B1 isolates were identified by neutralisation tests on the tissue culture fluids.

Neutralisation tests. Blood samples were collected in October 1976 and October 1977, the sera were stored at $-20^{\circ} \mathrm{C}$ until tested. Serum neutralisation tests were carried out in flat-bottomed microtitre trays using $0.05 \mathrm{~cm}^{3}$ unit volumes. Serum dilutions were prepared in the trays and 1 unit volume of Coxsackie B1 virus was added to each serum dilution. After mixing, trays were left at room temperature for one hour, when 1 unit volume of a suspension of Vero cells was added to each well. Trays were incubated in a moist chamber for 3 days at $35^{\circ} \mathrm{C}$. Presence of specific antibody was judged by inhibition of cytopathic effect. Sera with titres $<$ one in 20 were recorded as 'without antibody'.

\section{Results}

Clinical findings. The 5 boys were aged between 12 and 13 years. All complained of headaches and 


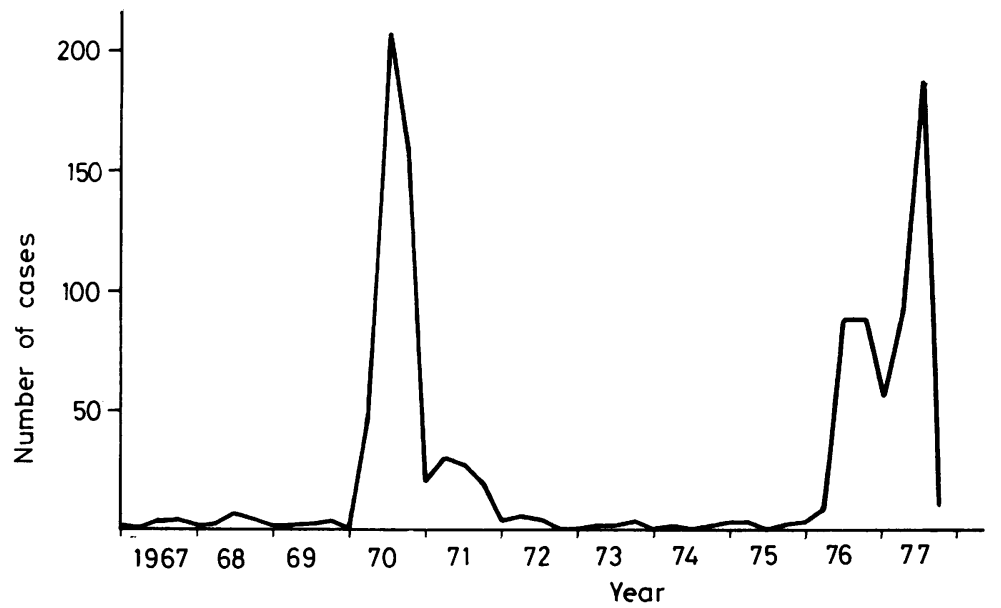

Figure Number of cases in which Coxsackie B1 was isolated during the years 1967-77 (from the Communicable Disease Reports of the Public Health Laboratory Service). sore throats, and 4 of them had fevers of $>38 \cdot 3^{\circ} \mathrm{C}$. In these boys the fever lasted from 2 to 5 days and the total length of illness was 6 . In 2 boys there was some injection of the fauces and, in a 3rd, slight neck stiffness. The 5 th boy was not pyrexial and spent only one day in the school infirmary. Convalescence was uncomplicated and there were no sequelae.

Epidemiology. During the period 13th June-11th July 1977, throat swabs were taken from 18 boys in the junior houses. Coxsackie B1 was isolated in 5 . There were no viral isolates in the remaining 13. Throat swabs were also taken from 28 boys in the senior houses, none of which showed evidence of Coxsackie B1 infection. Thus, from these results and the clinical picture, the outbreak appears to have been confined to the junior houses. 124 new entrants in October 1976 had had sera taken. $24(19 \%)$ had Coxsackie B1 antibodies and $100(81 \%)$ were negative. By 1977, 18 of these were positive, suggesting that $18 \%$ of the boys known to have been susceptible to the infection had developed antibodies during the previous year. These included 2 with positive throat swabs.

\section{Spread in the classrooms}

The boys from the junior houses are in three form groups-II, III, and LE. Table 1 shows that the 5 boys with positive throat swabs were in forms IIB, IIIA, B, C, and E. The results of the neutralisation tests show that, of the 124 boys who had paired sera taken in the individual classes, there does not appear to be any association between the clinically

Table 1 Results of Coxsackie B1 neutralisation tests and isolations in throat swabs according to school form

\begin{tabular}{|c|c|c|c|c|c|c|}
\hline \multirow[t]{3}{*}{ Form } & \multirow{2}{*}{\multicolumn{2}{|c|}{$\begin{array}{l}\text { Throat swabs } \\
\text { Coxsackie BI }\end{array}$}} & \multicolumn{4}{|c|}{ New entrants 1976} \\
\hline & & & \multirow{2}{*}{$\begin{array}{l}\text { Sera } \\
\text { taken }\end{array}$} & \multirow{2}{*}{$\begin{array}{l}\text { Negative } \\
1976\end{array}$} & \multicolumn{2}{|c|}{ Converted 1977} \\
\hline & Isolated & Not isolated & & & No. & $\%$ of negative \\
\hline $\begin{array}{l}\text { IIA } \\
\text { IIB } \\
\text { IIC } \\
\text { IID } \\
\text { IIE }\end{array}$ & $\begin{array}{l}0 \\
1 \\
0 \\
0 \\
0\end{array}$ & $\begin{array}{l}0 \\
0 \\
1 \\
0 \\
2\end{array}$ & $\begin{array}{l}16 \\
19 \\
19 \\
17 \\
17\end{array}$ & $\begin{array}{l}11 \\
16 \\
16 \\
11 \\
13\end{array}$ & $\begin{array}{l}3 \\
3^{*} \\
5 \\
1 \\
2\end{array}$ & $\begin{array}{r}27 \\
19 \\
31 \\
9 \\
15\end{array}$ \\
\hline $\begin{array}{l}\text { IIIA } \\
\text { IIIB } \\
\text { IIIC } \\
\text { IIID } \\
\text { IIIE } \\
\text { IIIF } \\
\text { IIIG } \\
\text { LE } \\
\text { Total }\end{array}$ & $\begin{array}{l}1 \\
1 \\
1 \\
0 \\
1 \\
0 \\
0 \\
0 \\
5\end{array}$ & $\begin{array}{r}2 \\
0 \\
1 \\
0 \\
0 \\
2 \\
0 \\
5 \\
13\end{array}$ & $\begin{array}{r}9 \\
7 \\
9 \\
2 \\
4 \\
5 \\
0 \\
0 \\
124\end{array}$ & $\begin{array}{r}9 \\
7 \\
7 \\
2 \\
3 \\
5 \\
0 \\
0 \\
100\end{array}$ & $\begin{array}{c}3^{*} \\
0 \\
1 \\
0 \\
0 \\
0 \\
0 \\
18\end{array}$ & $\begin{array}{l}\frac{33}{14} \\
- \\
- \\
- \\
- \\
\overline{18}\end{array}$ \\
\hline
\end{tabular}

*Also had a positive throat swab. 
confirmed cases and those with serological evidence of a subclinical infection. In forms IIB, IIIA, and IIIC, both clinical and subclinical infection occurred. In forms IIIB and IIIE, both with clinical cases, there was no evidence of seroconversion among those who had paired sera taken, whereas in forms IIA, C, D, and E where there were no clinical cases, there was serological evidence of subclinical infection.

\section{Spread in the dormitories}

Table 2 shows that the 5 ill boys with positive swabs came from two houses-Leigh Hunt A and Barnes A. Each of the six junior houses has two dormitories with about 30 boys in each. The distance between any two beds is $900 \mathrm{~mm}$ in accordance with The Standards for School Premises Regulations (Great Britain Statutory Instruments, 1972). In Leigh Hunt A one of the boys with a positive throat swab slept in the upper dormitory and the two others in the lower dormitory. In Barnes A one was in the upper and one in the lower dormitory.

The proportion of boys who had paired sera taken was similar in each house.

In Leigh Hunt $A$, of the 7 boys who had seroconverted, 4 slept in the upper dormitory, 3 of them in adjacent beds. The beds of the 3 in the lower dormitory were not close together.

In Leigh Hunt B, all 4 boys with a subclinical infection came from the upper dormitory. One had been sleeping in the infirmary throughout June because of nocturnal epilepsy.

In Barnes $A$, the 3 boys who had seroconverted slept in widely separated beds in the upper dormitory.
(Paired sera had not been taken from the clinical cases.)

In Barnes B, 4 boys had evidence of a subclinical infection. One slept at home and the remaining 3 boys were in the lower dormitory and slept in adjacent beds. There was no evidence of infection in the upper dormitory.

There were no known cases, clinically or subclinically, in the four dormitories of Maine A and B, although $83 \%$ of the boys in these houses had no detectable antibody to Coxsackie B1 in October 1976.

Thus, clinical and known subclinical infection was confined to 6 of the 12 dormitories. In two houses the infection occurred in only one dormitory. Of the 18 boys with paired sera who showed evidence of infection, two groups of 3 slept in adjacent beds.

\section{Discussion}

The Coxsackie B group of viruses are associated with a broad spectrum of clinical illness, ranging from a mild febrile infection to severe encephalitis (Kibrick, 1964; Assaad and Cockburn, 1972). A fatal case due to Coxsackie B1 in a newborn baby has been reported (Wright et al., 1963).

This outbreak was not serious in itself. The results suggest that the dormitories and sleeping quarters are more important than the day-to-day contacts in the spread of this infection. While this has obvious implications in boarding schools and children's homes, it also raises the question of the advisability of nursing children with known or

Table 2 Results of Coxsackie B1 neutralisation tests and isolation in throat swabs 1976 and 1977 according to school house

\begin{tabular}{|c|c|c|c|c|c|c|}
\hline & $\begin{array}{l}\text { Leigh } \\
\text { Hunt A } \\
(n=63)\end{array}$ & $\begin{array}{l}\text { Leigh } \\
\text { Hunt B } \\
(n=63)\end{array}$ & $\begin{array}{l}\text { Barnes } \\
A \\
(n=60)\end{array}$ & $\begin{array}{l}\text { Barnes } \\
B \\
(n=61)\end{array}$ & $\begin{array}{l}\text { Maine } \\
A \\
(n=60)\end{array}$ & $\begin{array}{l}\text { Maine } \\
B \\
(n=61)\end{array}$ \\
\hline \multicolumn{7}{|l|}{ Throat swabs } \\
\hline No. positive & 3 & $\mathbf{0}$ & 2 & 0 & 0 & 0 \\
\hline No. negative & 1 & 6 & 1 & 0 & 4 & 1 \\
\hline \multicolumn{7}{|l|}{ New entrants 1976} \\
\hline No. of boys with paired sera & 22 & 22 & 17 & 21 & 21 & 21 \\
\hline \multicolumn{7}{|l|}{$\begin{array}{l}\text { Of those with paired sera } 1976 \\
\text { with antibodies }\end{array}$} \\
\hline No. & 3 & 2 & 6 & 6 & 2 & 5 \\
\hline $\begin{array}{l}\% \\
\text { without antibodies }\end{array}$ & 14 & 9 & 35 & 29 & 10 & 24 \\
\hline No. & 19 & 20 & 11 & 15 & 19 & 16 \\
\hline$\%$ & 86 & 91 & 65 & 71 & 90 & 76 \\
\hline \multicolumn{7}{|l|}{$1977^{\circ}$ converted } \\
\hline No. & $7^{*}$ & 4 & 3 & 4 & 0 & 0 \\
\hline$\%$ & 32 & 18 & 18 & 19 & 0 & 0 \\
\hline
\end{tabular}

*Includes two boys with positive throat swabs. 
suspected enterovirus infections-for example aseptic meningitis-in open wards in hospital.

We thank Mr Richard Pollard for preparing the diagram, the boys of Christ's Hospital for their co-operation, and $\mathrm{Dr}$ T. M. Pollock, Director of the Epidemiological Research Laboratory, for his interest and encouragement.

\section{References}

Assaad, F., and Cockburn, W. C. (1972). Four year study on WHO virus reports on enteroviruses other than poliovirus. Bulletin of the World Health Organisation, 46, 329-336.

Broughton, D. H., and Gostling, J. V. T. (1969). An illness associated with Coxsackie virus B2 in a residential school. Practitioner, 202, 285-289.

Carmichael, J., McGuckin, R., and Gardner, P. S. (1968). Outbreak of Coxsackie type B2 virus in a children's home in Newcastle upon Tyne. British Medical Journal, 2, 532-533.

Eilard, T., Kyllerman, M., Wennerblom, I., Eeg-Olofsson, O., and Lycke, E. (1974). An outbreak of Coxsackie virus type B2 among neonates in an obstetrical ward. Acta paediatrica Scandinavica, 63, 103-107.

Great Britain Statutory Instruments (1972). The Standards for School Premises Regulations, No. 2051. HMSO: London.

Hoskins, T. W., Davies, J. R., Smith, A. J., Allchin, A. Miller, C. L., and Pollock, T. M. (1976). Influenza at Christ's Hospital: March 1974. Lancet, 1, 105-108.

Kibrick, S. (1964). Current status of Coxsackie and ECHO viruses in human disease. Progress in Medical Virology, 6, 27-70.

Lapinleimu, K., and Kaski, U. (1972). An outbreak caused by Coxsackie virus B5 among newborn infants. Scandinavian Journal of Infectious Diseases, 4, 27-30.

Public Health Laboratory Service (1964-1977). Communicable Disease Reports (Quarterly). Public Health Laboratory Service: London.

Yodfat, Y., and Nishmi, M. (1973). Epidemiologic and clinical observations in six outbreaks of viral disease in a kibbutz, 1968-1971. American Journal of Epidemiology, 97, 415-423.

Wright, H. T., Jr, Okuyama, K., and McAllister, R. M. (1963). An infant fatality associated with Coxsackie B1 virus. Journal of Pediatrics, 63, 428-431.

Correspondence to Dr R. N. Chamberlain, Central Public Health Laboratory Service, Epidemiological Research Laboratory, Colindale Avenue, London NW9 5HT.

Received 8 August 1978 